\title{
Correspondence
}

\section{Bray's discovery of pathogenic Esch. coli as a cause of infantile gastroenteritis}

Sir,

May I comment on the recent article under the above heading in the Archives (1973, 48, 923) where Bray and Beaven are given the credit for having discovered the role of pathogenic Esch. coli in infantile gastroenteritis. It would be a pity if the much earlier work of my former teacher A. Adam was to be forgotten. In 1923 he first identified special types of lactose-splitting Esch. coli as a cause of severe infantile gastroenteritis. In 1927 he further established the so-called dyspepsia-coli-types A1 and AIV. This work was confirmed using serological methods by Goldschmidt (1933). Further details are to be found in Adam's book Säuglingsenteritis (1956).

Without doubt the rediscovery of 'dyspepsia coli' by Bray and Beaven was extremely important, but we should not forget the earlier work published in the German literature.

\section{O. H. BRAUN \\ Kinderklinik des Städt Krankenhauses, Pforzheim, Germany.}

Sir,

May I just attract your attention to a point in the December 1973 number of the Archives. The first article under 'Looking back' is entitled 'Bray's discovery of pathogenic Esch. coli as a cause of infantile gastroenteritis'. I would be the last to detract from John Bray's important contribution to the aetiology of infantile gastroenteritis. The commemorative plaque expresses it clearly that he was the first to provide convincing proof of the major cause of severe gastroenteritis.

However, if one would look a little bit further back, one would find that $\mathrm{A}$. Adam published in 1923 an article on the aetiological significance of Esch. coli (Adam, 1923, 1927; Adam and Froboese, 1925).

I have no access to the journals at the moment and therefore only quote from memory. But as far as I remember Adam was able to show the invasive type of Esch. coli by showing its presence in the mucosa and submucosa of the small intestine in infants who died of so-called alimentary intoxication.

Adam has died some years ago; a disappointed man that his studies had gone unnoticed and to a large extent deliberately ignored, because at the time the hypothesis of the food induced severe forms of gastroenteritis was the official attitude of paediatricians in Germany.

A. HOLZEL

St. Mary's Hospital, Hathersage Road, Manchester M13 OJH.

REFERENCES

Adam, A. (1923). Utber die Biologie der Dyspepsiecoli und ihre Beziehungen zur Pathogenese der Dyspepsie und Intoxikation. fahrbuch für Kinderheilkunde, 101, 295.

Adam, A. (1927). Dyspepsiekoli. Zur Frage der bakteriellen Ätiologie der sogenannten alimentären Intoxikation. fahrbuch für Kinderheilkunde, 116, 8.

Adam, A. (1956). Säuglingsenteritis. Thieme, Stuttgart.

Adam, A., and Froboese, C. (1925). Untersuchungen zur Pathologie der Durchfallserkrankungen des Sauglings. Zeitschrift für Kinderheilkunde, 39, 267.

Goldschmidt, R. (1933). Untersuchungen zur Ätiologie der Durchfallserkrankungen des Säuglings. Fahrbuch für Kinderheilkunde, 139, 318. 